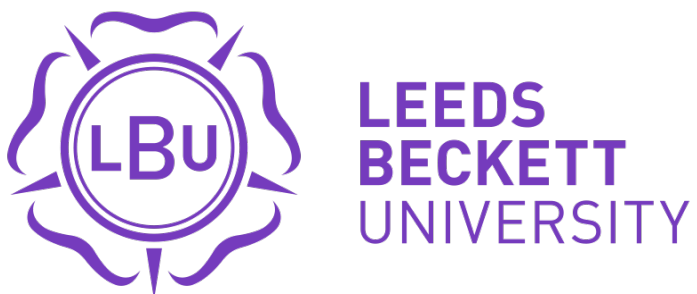

Citation:

Bradley, Q (2020) A Passion for Place and Participation. In: The Routledge Handbook of Place. Routledge, London. ISBN 1138320498, 9781138320499

Link to Leeds Beckett Repository record:

http://eprints.leedsbeckett.ac.uk/6988/

Document Version:

Book Section

The aim of the Leeds Beckett Repository is to provide open access to our research, as required by funder policies and permitted by publishers and copyright law.

The Leeds Beckett repository holds a wide range of publications, each of which has been checked for copyright and the relevant embargo period has been applied by the Research Services team.

We operate on a standard take-down policy. If you are the author or publisher of an output and you would like it removed from the repository, please contact us and we will investigate on a case-by-case basis.

Each thesis in the repository has been cleared where necessary by the author for third party copyright. If you would like a thesis to be removed from the repository or believe there is an issue with copyright, please contact us on openaccess@leedsbeckett.ac.uk and we will investigate on a case-by-case basis. 
Bradley, Q. (2020) A passion for place and participation. In: Edensor, T., Kalandides, A., Kothari, U. (eds) The Routledge Handbook of Place. London. Routledge. Chapter 35.

\section{A Passion for Place and Participation}

By Quintin Bradley

This chapter is about the bond between place and participation, or the idea that devolving decisions to local neighbourhoods makes for a more participatory democracy. It concerns the practices of 'community localism' or the devolution of statutory governance to local neighbourhoods. The key assumption underpinning the state rationality of localism is that the smallest geographical unit of governance - the local neighbourhood or place - provides the greatest opportunities for citizens to participate in decisions (Lowndes \& Sullivan, 2008). The local becomes in this rationality a metaphor for empowerment and democratisation. It is implied that devolution to neighbourhoods automatically makes decision-making more participatory. This has been dubbed 'the local trap' by scholars who point out that there is nothing intrinsic to local-scale decision-making to guarantee greater popular participation (Purcell 2006). This chapter argues against that common-sense view. It maintains that places can be more democratic simply because they are more local.

The argument is constructed over three sections. In the first I explore the role of place in regulating social relations and establishing norms of behaviour, and I discuss the spatial divide between the behaviours associated with the domestic realm of neighbourly care - the place of community - and those associated with the formal economy of public and political life - the place of governance. In the second section, I introduce the state rationality of localism as a breach of spatial boundaries across this division of labour. Localism provides the legislative and institutional permissions that enable people in domestic spaces to practice democratic governance and to 'scale-up' an economy of reciprocity and neighbourly care into political participation (Smith 
1993). In the third section, I discuss the spatial technologies of community localism that enable places and their associated behaviours to be changed and rendered more participative. I advance the concept of community identity frames to explain the practices through which place can be co-produced as neighbourly and neighbourly relations can be transformed into more formal processes of participative democracy (Bradley, 2014; 2017). The chapter concludes that the identity work done by communities is a political project through which participatory governance is established as a social relationship of place and places become both local and more participative.

\section{Place and subjectivity}

Places have meaning and purpose. Physical and social settings are inscribed with meanings that govern expected behaviour and social interaction (Goffman 1969; Jenkins 2008). It is through place that the roles and categories that define social identity are learned and internalised (Manzo \& Perkins 2006). Dominant place meanings are established through authorised discourses and practices. The role of statutory town and country planning systems, for example, is to allocate particular land uses to specific places. Planning decrees the activities of place in broad terms: it identifies land for residential uses, or retail or for light industrial use. This allocation of use to land attributes specific behaviours to places (Lefebvre, 1991). Shopping malls expect visitors to shop. Often there is an element of coercion in place to ensure that people abide by these spatial codes. Security guards may exclude young people from shopping malls if they are conspicuously failing to consume. Some of these forms of coercion are subtle and are exerted through peer pressure and through everyday social relations. Friends may tell you to 'lighten up' at a nightclub or 'quiet down' in a library. In many ways, our subjectivity, what we think as well as what we say and do, and how we present ourselves, is actively performed by the meanings of the places we occupy. In company with the feminist theorist Judith Butler (1997), we can understand this as a form of citational practice. Places are encoded with normative prescriptions about how they should be used and what values, social behaviour and relationships are to be associated with them. In our social relations we cite, or 
reference, as if it was a body of literature, this spatial code. In the course of everyday life, we 'read' places and reference their invisible rules in our behaviour and comportment (Moisio \& Luukkonen, 2015). Place is then an active agent in cementing social distinctions and hierarchies and in maintaining inequality and injustice. The most evident impact on equality is in the distinction between private and public places where spatial codes map onto a gendered division of labour between the domestic and formal economies (Staeheli, 2002). The encoding of place as public or private, residential or economic, assigns different status to the labour of women and men. It marks out notional divisions in society between the 'economy' and the 'community' and depoliticises as it moralises the domestic sphere (Roy, 2001; Spivak, 2010).

In her theory of performativity, Judith Butler argued that socio-spatial positioning (her focus was on the gendered body) is made concrete through the repeated citation of regulatory norms. As we repeatedly reference the invisible rules of place and adapt our behaviour accordingly, our behaviour becomes increasingly constrained and predictable. This is an active process and we may do it slightly differently each time, although Butler is at pains to point out our behaviour is 'regularised' (Butler 1993: 95). Place becomes part of our subjectivity in this way. We are the embodiment of regulated space. Butler (1997: 10) maintained that this regulation acted on, and through, our relationship to place; she wrote: 'Individuals come to occupy the site of the subject (the subject simultaneously emerges as a "site")'. The subject of regulation is our relationship with place; we can be put in our place, or we can be out of place. We are always a subject-in-place. It might follow from this that any change to a place may also present opportunities to change the behaviours associated with that place. Just as what is expected of us, and what we are expected and authorised to do and say changes as we move from one place to another, we might argue, along with Butler, that we can subvert the meaning of spaces, and occupy them in ways that expand and potentially transform their normative use and restrictions. The accent here is on the active and emergent nature of place (Jupp 2008: 334). Places and our relationship with them, are continuously subject to reproduction and reinterpretation that projects 'the instability and incompleteness of subject-formation' (Butler 1993: 226). 
In The Production of Space Henri Lefebvre (1991) famously classified our relationship with place into three dialectically entangled spatial elements, as conceived, perceived and lived. This spatial triad can provide a conceptual model for theorising how the regulatory power of place may be challenged. In conceptualising his triad Lefebvre located the motor for reiterative change in lived space, or representational space that 'the imagination seeks to change and appropriate' (Lefebvre 1991: 39). He recognised that the 'living' of space is coloured by the imagination, and by memories and emotional associations that have the potential to produce variances in the normative processes through which the subject-in-place is reproduced. The meanings that are attached to place through residence, and through familiarity and routine 'living', may be in conflict with the spatial codes of formal practices, such as those of the town and country planning system. Everyday reiterative practices make space familiar and malleable, so that its spatial codes and its meaning can be transformed. Repeated experience, familiar daily routines and established paths transform space so that it 'gets under the skin' and becomes a 'field of care' (Tuan 1979: 418). We can understand this as a practise of domestication, of making space familiar, so as to enlarge the range of possibilities encoded within it. This is a practice associated with residence, with place attachment and with the concept of community. As Butler stressed it involves repetition and familiarity, but as Lefebvre points out, it is also about the imagination, and about a passion for place. We can transform a place in our minds, and we can see how it could it could be changed through our actions. Becoming attached to a place might give us licence to act differently; it might offer us a greater range and freedom of action, and more room to breathe.

We associate place attachment with community, and the work of community and neighbourhood groups or associations. While community groups are largely confined to the private and the domestic sphere, they have become increasingly central to political strategies. In the next section I discuss the state rationality of localism and the licence it offers communities to challenge the subjectivity of place.

$\underline{\text { Localism, place and democracy }}$ 
A promise to devolve decision-making to local communities has been a constant theme in the political strategies of localism that have been central to the restructuring of state power since the 1970s. State relations of government have been widely transformed into new assemblages of distributed governance that have promised 'a reordering of public space' (Mohan \& Stokke, 2000: 250), attributing political content to a particular spatial form in their conflation of the local with better and more democratic governance (Painter, Orton et al., 2011). In constituting the local as a metaphor for democracy, community localism foregrounds the pivotal role played by place in cementing social differentiation and in naturalising power relations (Marston, 2000). By conflating community governance with empowerment, localism makes socio-spatial positionalities visible and, at the same time, makes them the object of political attention and therefore vulnerable to change (Leitner, Sheppard \& Sziarto, 2008).

Community localism is presented as a transfer of responsibility from the state to the community; it builds on, and seeks to co-opt into governance, a long tradition of grass roots activism and neighbourhood campaigns focused on the local welfare state (Hall \& Massey, 2010; Williams, 1993). The mobilisation of urban social movements around place as community has, if anything, been renewed by the ubiquity of the concept in government discourse. The ability of community groups to move fluidly from campaigning for improvements in local services, to running them, and back again, has been a subject of particular commentary among feminist scholars (Newman, 2012). Community action manifests itself as an ethic of care extended into the public sphere of governance. It mobilises household reproductive labour as a model of co-operation on which to reconstruct the local welfare state (Abel \& Nelson, 1990). It borrows from an economy of reciprocity exemplified by the informal provision, most often by women, of material and immaterial help through extended family and neighbourhood networks (Williams \& Windebank, 2000). The high levels of trust necessary to support this economy of care were founded on the geographical immobility of women (McCulloch, 1997) and developed in the absence of alternative means of surviving 'as an extended subterranean chain' of services and good deeds (Bulmer, 1986: 112). This is what Raymond Williams called 'the positive practice of neighbourhood' that aims to 
foster the social relations of community as a model for the collective organisation of society; 'the basic collective idea' that 'the provision of the means of life will, alike in production and distribution, be collective and mutual' (Williams, 1958: 326). It is also, and paradoxically, a relationship that can be commodified in the form of social capital, an adaptable coinage that awards an exchange value to economies based on use value, and that resonates with governmental discourses of responsibility, enterprise and active citizenship (Portes, 1998).

The rationality of localism extends an invitation to community and neighbourhood organisations to take part in the governance of place and to take responsibility for the delivery of statutory services. Localism relocates the domestic norms of a gendered private space to the public sphere, promising that politics can be brought within reach and made subject to the rhythms of daily interaction. This is a breach of spatial boundaries that superimposes the public space of formal governance onto the private sphere of place attachment and neighbourly care. The exercise of formal governance in a residential and domestic setting suggests that the public space of democracy can be enacted as domestic and familiar and that power and decision-making can be made neighbourly and brought within reach. In doing so, it locates political space within familiar patterns of place attachment and neighbourliness and suggests that questions of power and governance can be decided on a domestic scale (Smith, 1993). To change the meaning of space is to create the possibility that people, and their social relations can change. The engagement of neighbourhood groups and community organisations in the devolved governance of localism appears as a political struggle over the value and meaning of place and the social relations it prescribes (Mihaylov \& Perkins 2015). It is a conflict over knowledge and power and the role that place plays in the creation, maintenance and transformation of social identity (Haraway, 1991).

The political technology of localism gives license to community action at the same time as it seeks to embrace communities as the embodiment of a responsible and governable public. It provides institutional forms and regulatory permissions through which the boundaries of political space may be moved into new alignments and confers the privileges of statutory authority on an moral economy of reciprocity and 
neighbourly care. In its rhetorical conflation of place and participation it provides the spatial codes through which resident-led organisations can attempt to construct place as both local as participative.

\section{Constructing place as participation}

The adoption of methodologies of participation by resident organisations and neighbourhood groups has been widely perceived as a response to a crisis of legitimacy in representative democracies. Formal processes of delegation and electoral accountability are seen as insufficient for the construction of a democratic society (della Porta et al, 2017). Participatory theory envisions the maximum participation of citizens in their own governance, especially in sectors of society beyond those that are traditionally understood to be political (Pateman, 1970). By taking part in decisions directly, people are expected to acquire political competencies and experience a heightened sense of political efficacy and empowerment. This is a theory of democratisation; of the extension of democracy into civil society, into the economy and into the neighbourhood (Hilmer, 2010).

The political ubiquity of public participation has transposed the legitimacy concerns of representative democracies onto the new publics empowered by the political rhetoric of localism. Participatory theory is associated with the pursuit of political equality as a 'process where each individual member of a decision-making body has equal power to determine the outcome of decisions' (Pateman, 1970: 71). In practice, the resource inequality intrinsic to the operation of market societies presents an almost insurmountable obstacle to attempts to achieve political justice through the direct popular representation of interests (Dahl, 1998; Freeman, 1970; Mansbridge, 1973). The absence of traditional procedures of authorisation and accountability has provoked criticism that participatory initiatives are open to capture by private interests, and that participants are drawn inequitably from those with existing attachments and the means to influence decision making. 
Groups that lack a convincing electoral mandate may construct other forms of democratic legitimacy in their claim to represent a defined constituency or locality. Pitkin (1967) identified 'descriptive representation' as the system of legitimacy most associated with public participation and direct democracy. In descriptive representation the absence of formal methods to enable accountability are mitigated by a correspondence between a specific public, their experiences, interests or demographic make-up and those who represent them as their political surrogates (Mansbridge, 2003). There is an unavoidable ambiguity in the precise nature of this correspondence. In her influential work 'Can the subaltern speak?', the post-colonial theorist Gayatri Chakravorty Spivak (1988: 276) pointed to the distinction between representation as proxy, and representation as an act of signification. A definition of representation as 'acting for' or 'standing for' ignores 'the constitutive dimension of representation' (Saward, 2010: 9). The claim to correspondence with a specific public, a place, and a set of interests, entails an act of signification in which a portrait of a community of place and interests is created. The idea of a constituency that can be spoken for, and a set of interests that can be represented, is a work of identification that manifests a specific public, and that accords it voice, needs and preferences. To understand the act of descriptive representation as signification is to attend to identity work as a democratic practice: the framing of collective identities around place and constituency, and the democratic contentions that arise as identities are challenged, debated, and transformed.

A collective identity is framed around shared residence in a defined territory and the proximity of representatives to their constituency, signifying their physical closeness to the designated public (Houtzager \& Lavalle, 2010; Piper \& von Lieres, 2015). Participation is here understood as a condition of 'nearness' in which routine interaction and face-to-face encounters provide the mechanism for accountability between represented and representative (Kearns \& Parkinson 2001). Peter Somerville (2005: 122) identified the democratic processes associated with living in nearness: 'The high probability of repeated interaction within a community means that members have a strong incentive to act in socially beneficial ways to avoid retaliation next time. Frequent interaction lowers the costs and raises the benefits associated 
with discovering more about the characteristics, recent behaviour and likely future actions of other members.'

The routine social interactions that constitute nearness as participative democracy have to be actively constructed through 'neighbouring' work (Bulmer, 1986). Transforming place into nearness means bringing decision-making within reach by embedding it in the rhythms of reciprocity and neighbourly care. In addition to the implied accountability of physical proximity, the claim to democratic legitimacy through nearness conveys possession of a shared local knowledge. The representatives claim to know the interests and concerns of their constituents, because they are in regular contact with them and because they share the same familiar space of community, or nearness in the neighbourhood (Bradley 2014). The claim to local knowledge is a necessary adjunct to the substantive action of representation which entails speaking for, and acting in, the known interests of the public (Pitkin, 1967). The notion that shared turf entails shared knowledge presumes a set of interests that come attached to nearness and that have to be actively constructed as a collective identity through the practice of neighbouring.

The connection between place and the construction of collective identities has been captured in the concept of community identity which describes emotional connections to the locality and to its cultural context (Puddifoot, 1995; Long \& Perkins, 2007). Community identity encapsulates the attribution of distinctive meaning to place and the association of place with enhanced behaviours and changed social relations (Puddifoot, 2003). It transcends the individual responses to place attachment and place identity familiar to the literature of environmental and community psychology and signals, instead, a process of collective identification, in which the passions of place translate into statements of social and political purpose (Dixon \& Durrheim 2000; Kyle, Mowen \& Tarrant, 2004). This collective work of identification has been dubbed 'place framing' by Martin (2003) and is typically associated with community groups and neighbourhood organisations who integrate the multiple values that residents ascribe to place into a convincing narrative to mobilise collective action. 
Martin drew on the social movement concept of collective action frames (Benford and Snow, 2000), to explain how organisational discourses are assembled by neighbourhood groups to inspire and legitimise place-protective action. In social movement studies, the technique of frame analysis (Snow et al., 1986) has become a key diagnostic tool for interpreting the discursive assemblage of shared identities that is necessary for groups to mobilise collective action and generate plans for change. Martin's thesis was limited to a discussion of the place definition work carried out by community activists to build local organisations. Further development of the concept of place frames is required to understand the impact of identity work on place and its social relations. One approach to this analysis is through the social movement concept of collective identity frames. Collective identity frames (Melucci, 1995) are emotional and often passionate constructs that are negotiated, elaborated and developed in group relationships and acquire their resonance through widely-shared and familiar symbols, interpretations, and self-definitions (Polletta \& Jasper, 2001). They represent an assemblage of three collective identity processes: the demarcation of group boundaries, the production of a repertoire of shared values, and the promotion of collective efficacy or belief in the ability of the group or organisation to bring about change (Taylor \& Whittier, 1992). Applied to the place-based work of community organisations, the theory of collective identity broadens Martin's outline of place framing to connect place to participation and to show how place framing can encode space with the social relations of nearness.

My concept of community identity frames enables connections to be drawn between place attachment and the practices of identity work diagnosed by social movement theorists. A community identity frame does not only assert a common identification of place but forges a connection between place characteristics and particular social relations. It seeks to encode place with specific social meanings that legitimise and normalise a defined set of spatial practices. These in turn, provide the rationale for the claims of community organisations to represent their neighbourhood and for the conditions of nearness that enable the practices of participative democracy. A community group and their representatives must assemble a resonant frame of 
community identity from the diverse and potentially conflicting place meanings expressed and felt by residents so that it amplifies a shared sense of place and enhances feelings of belonging and capability. Community identity frames are a negotiation rather than a defined agreement, and the test of participatory democracy is the extent to which publics are able to organise and articulate their competing interests in nearness, and either reach a negotiated settlement or continue to contest the issue (Marres, 2005). In highly diverse neighbourhoods, it can be argued that community identity frames are a project of manufactured unity in which a coherent vision of place is distilled from discordant views, potentially to mobilise a population despite tensions and divisions. In small rural communities, the community identity frame might serve to amplify a shared sense of place and enhance feelings of belonging and capability (Bradley, 2017).

A community identity frame provides a sense of place and the social relations associated with it. It invokes shared interests and local knowledge and promotes a sense of living in 'nearness'. This identity work roots participatory governance in the everyday labour of reciprocity and care. It lays the foundations for the descriptive representation essential to participatory democracy and produces place as both neighbourly and democratic, as the final section explains.

\section{Participation and place: a conclusion}

The transposition from neighbourhood as place to neighbouring as an activity and on to nearness as a condition of being is the root of the concept of community and its bond with participatory democracy. Neighbourhood organisations aim to construct a resonant frame of community identity that assembles a public around a characterisation of place as neighbourly and participative. This collective identity frame is distilled into a spatial code to invoke the subjectivities of distinctive environments and establish norms of social relations. The spatial norms assembled in a community identity invoke a particular public and implicitly align place with an emplaced culture or, to borrow a phrase from organisational theory, 'a way of doing 
things around here' (Bower, 1966: 4). Places are rendered as capable of managing their own affairs, as holding duties of care and stewardship, and are represented as civic polities where collective decisions can be taken. Although this collective identity appears as a discursive construction it is inscribed on place through the repeated citation of regulatory norms. Community representatives are rendered representative through active proximity and everyday interaction. The routine labour of neighbourly care provides the communicative networks that sustain participation in community decisions. To this community identity of participative nearness, the state rationality of localism adds the permissions and opportunities of legislative framework and institutional form. Community groups may assume devolved responsibility for devising a statutory plan for neighbourhood development, build and manage community housing or take over the delivery of local services. Localism gives licence to the democracy of nearness and the local becomes a place of empowerment and democratisation through the practice of participatory governance as neighbourly care. In this way, despite all evidence to the contrary, the smallest geographical unit of governance provides the greatest opportunities for citizens to participate in decisions.

\section{$\underline{\text { References }}$}

Benford, R. \& Snow, D. (2000) Framing Processes \& Social Movements: an overview and assessment. Annual Review of Sociology. Vol. 26: 611-63i

Bradley, Q (2017) Neighbourhood planning and the impact of place identity on housing development in England. Planning Theory \& Practice. Vol.18 (2): 233-248 Bradley, Q. (2014) Bringing democracy back home: community localism and the domestication of political space. Environment \& Planning D: Society \& Space. Vol.32. No. 4: $642-657$

Bulmer, M. (1986) Neighbours: the work of Philip Abrams. Cambridge. Cambridge University Press.

Butler, J. (1993) Bodies that Matter: on the discursive limits of sex. London. Routledge. Butler, J. (1997) Excitable Speech: a politics of the performative. London. Routledge 
Bower, M. (1966) "The way we do things around here" A New Look at the Company Philosophy. Management Review. Vol. 55 (5): 4-11

Dahl, R. (1998) On democracy. London. Yale University Press

Della Porta, D., F. O'Connor, M. Portos \& A.S. Ribas (2017) Social movements and referendums from below: direct democracy in the neoliberal crisis. Bristol. Policy Press. Dixon, J. \& K. Durrheim (2000) Displacing place-identity: A discursive approach to locating self and other. British Journal of Social Psychology, 39: 27-44

Freeman, J. (1970/ 2013) The Tyranny of Structurelessness. WSQ: Women's Studies Quarterly, Vol. 41, 3 \& 4: 231-246

Hall, S. \& D. Massey (2010) Interpreting the Crisis. Soundings. No.44, Spring: 57-71

Haraway, D. J. (1991) Simians, cyborgs and women: the reinvention of nature. London. Free Association Books

Hildreth, P. (2011) What is Localism \& what implicatons do different models have managing the local economy. Local Economy. Vol.26, No.8: 702-714

Hilmer, J. (2010) The State of Participatory Democratic Theory. New Political Science. Volume 32, Number 1: 43-63

Houtzager, P. \& A. G. Lavalle (2010) Civil Society's claims to political representation in Brazil. Studies in Comparative International Development, 45:1-29

Jupp, E. (2008) The Feeling of Participation: everyday spaces and urban change. Geoforum. Vol. 39: 331-343

Kearns, A. \& M. Parkinson (2001) The Significance of Neighbourhood. Urban Studies. Vol. 38, No.12: 2103-2110

Kyle, G., A. Mowen, \& M. Tarrant (2004) Linking place preferences with place meaning: An examination of the relationship between place motivation and place attachment. Journal of Environmental Psychology, 24: 439-454

Lefebvre, H. (1991 [1974]) The Production of Space. Trans. D. Nicholson-Smith. Oxford. Blackwell

Leitner, H., Sheppard, E. \& K. Sziarto (2008) The Spatialities of Contentious Politics. Transactions of the Institute of British Geographers. Vol.33, No.2: 157-172 
Long, D.A. \& D. Perkins (2007) Community social and place predictors of sense of community: a longitudinal analysis. Journal of Community Psychology. Vol. 35. No.5: 563-581

Lowndes, V. \& H. Sullivan (2008) How Low Can You Go? Rationales and challenges for neighbourhood governance. Public Administration. Vol. 86, No. 1: 53-74

McCulloch, A. (1997) "You've Fucked Up the Estate \& Now You're Carrying a Briefcase!" In: Hoggett, Paul (ed.) Contested Communities: experiences, struggles, policies. Bristol. Policy Press.

Mansbridge, J. (2003) Rethinking representation. The American Political Science Review, Vol. 97, No. 4 (pp. 515-528

Mansbridge, J. (1973) Time, emotion and inequality: three problems of participatory groups. The Journal of Applied Behavioural Science. Vol. 9 Issue 2/3, p351-368

Manzo, L. \& D. Perkins (2006) Finding common ground: the importance of place attachment to community participation and planning. Journal of Planning Literature. Vol. 20, No.4: 335 - 350

Marres, N. S. (2005). No issue, no public: democratic deficits after the displacement of politics. Amsterdam. Ipskamp Printpartners

Martin, D. (2003) Place-Framing as Place Making: constituting a neighbourhood for organising and activism. Annals of the Association of American Geographers, 93, (3): 730-750

Melucci, A. (1995) The Process of Collective Identity. In: Johnston, H. \& B. Klandermans (eds.) Social Movements \& Culture. UCL Press, London

Mihaylov, N. \& D. Perkins (2015) Local environmental grassroots activism: contributions from environmental psychology, sociology and politics. Behavioural Sciences. Vol.5: 121-153

Mohan, G. \& K. Stokke (2000) Participatory development \& Empowerment: the dangers of localism. Third World Quarterly. Vol. 21, No. 2: 247-268

Moisio, S. \& J. Luukkonen (2015) European spatial planning as governmentality: an inquiry into rationalities, techniques and manifestations. Environment \& Planning C: Government and Policy. Vol. 22: 828-845 
Newman, J. (2012) Making, Contesting \& Governing the Local: women's labour and the local state. Local Economy. 27, 8: 846-858

Painter, J., Orton, A., Macleod, G., Dominelli, L., Pande, R. (2011) Connecting Localism \& Community Empowerment: research review and critical synthesis for the ARHC Connected Community Programme. Project Report. Durham. Durham University, Dept. of Geography \& School of Applied Social Sciences.

Pateman, C. (1970) Participation and democratic theory. London. Cambridge University Press

Piper, L. \& B. von Lieres (2015) Mediating between state and citizens: the significance of the informal politics of third-party representation in the global south. Citizenship Studies, 19,6-7: 696-713

Polletta, F. \& J. Jasper (2001) Collective Identity and Social Movements. Annual Review of Sociology. 27: 283-305

Portes, A. (1998) Social Capital: its origins and applications in modern sociology. Annual Review of Sociology. 24: 1-24

Puddifoot, J. (1995) Dimensions of Community Identity. Journal of Community and Applied Social Psychology. 5: 357-370

Puddifoot, J. (2003) Exploring 'personal' and 'shared sense of community identity in Durham city, England. Journal of Community Psychology. 31, 1: 87-106

Purcell. M. (2006) Urban Democracy and the Local Trap. Urban Studies. 43, 11: $1921-$ 1941

Roy, A. (2001) A 'public' muse. Journal of Planning Education and Research. 21: 109126

Saward, M. (2010) The representative claim. Oxford. Oxford University Press

Smith, N. (1993) Homeless/Global: scaling places. In: Bird, J, Curtis, B., Putnam, T., Robertson, G. \& L. Tucker (eds.) Mapping the Futures. London, Routlege: 87-119

Snow, D.; Rochford, E. B. Jnr.; Worden, S.; Renford, R. (1986) Frame Alignment Processes, Micromobilisation and Movement Participation. American Sociological Review, 51, (4): 464-481

Somerville, P. (2005) Community governance and democracy. Policy \& Politics. 33(1): $117-144$ 
Spivak, G. C. (1988) Can the Subaltern Speak? In: Nelso, Cary \& Lawrence Grossberg (eds.) Marxism \& the Interpretation of Culture. Chicago, University of Illinois Press Staeheli, L. (2002) Women and the Work of Community. Environment \& Planning A. Vol. 35, Part 5: 815-831

Taylor V and Whittier N (1992) 'Collective Identity in Social Movement Communities: Lesbian Feminist Mobilization', pp. 104-130 in A Morris and C. Twigger-Ross, C. \& D. Uzzell (1996) Place and identity processes. Journal of Environmental Psychology. Vol. 16: $205-220$

Tuan, Y. (1975) Place: an experiential perspective. The Geographical Review. Vol. 65, No.2: 151-165

Williams, F. (1993) Women \& Community. In: Bornat, J., C. Pereira, D. Pilgrim \& F. Williams (eds.) Community Care: a reader. Basingstoke. Macmillan Williams, Raymond (1958) Culture and Society. London. Chatto \& Windus.

Williams, C. \& J. Windebank (2000) Helping Each Other Out? Community exchange in deprived neighbourhoods. Community Development Journal. Vol. 35. No.2: 146-156 